MDPI is a member of

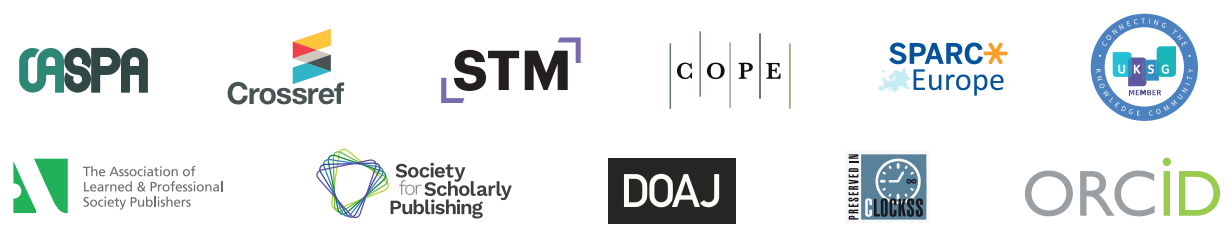

Affiliated Societies

an Open Access Journal by MDP ONAS

\section{IMPACT CITESCORE}

7.666

\title{
Follow
}

f facebook.com/MDPICells

3. twitter.com/Cells_MDPI

in linkedin.com/company/cells-mdp

(0) instagram.com/mdpiopenaccess

6) weibo.com/mdpicn

D. Wechat:MDPI-China

\section{Subscribe}

blog.mdpi.com

Visit mdpi.com for a full list of offices and contact information.

MDPI is a company registered in Basel, Switzerland, No. CH-270.3.014.334-3,

whose registered office is at St. Alban-Anlage 66, CH-4052 Basel, Switzerland.

Affiliated Societies:

Nordic Autophagy Society (NAS)

Signal Transduction Society (STS)

Society for Regenerative Medicine (Russian

Federation) (RPO)

Spanish Society for Biochemistry and

Molecular Biology (SEBBM)

Spanish Society of Hematology and

Hemotherapy (SEHH)

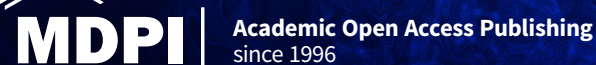

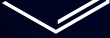




\section{cells}

an Open Access Journal by MDP

Editors-in-Chief

Prof. Dr. Cord Brakebusch

Prof. Dr. Alexander E. Kalyuzhny

Associate Editor

Dr. Bor Luen Tang

\section{Message from the Editors-in-Chief}

Cells has become a solid international scientific journal that is now indexed on SCIE and in other databases. We have successfully introduced a special issues format so that these issues serve as mini-forums in specific areas of cell science. Cells encourages researchers to suggest new special issues, serve as special issues editors, and volunteer to be reviewers. Our main focus will remain on cell anatomy and physiology, the structure and function of organelles, cell adhesion and motility, and the regulation of intracellular signaling, growth, differentiation, and aging. We are open to both original research papers and reviews.

\section{Author Benefits}

O Open Access Unlimited and free access for readers

C No Copyright Constraints Retain copyright of your work and free use of your article

\section{$\&$ Thorough Peer-Review}

(IF) 2021 Impact Factor: 7.666 (Journal Citation Reports - Clarivate, 2022)

S Discounts on Article Processing Charges (APC) If you belong to an institute that participates with the MDPI Institutional Open Access Program

$\succeq$ No Space Constraints, No Extra Space or Color Charges No restriction on the length of the papers, number of figures or colors

Coverage by Leading Indexing Services Scopus, SCIE (Web of Science) PubMed, MEDLINE, PMC, CAPlus / SciFinder, and many other databases

( Rapid Publication First decision provided to authors approximately 16.4 days after submission; acceptance to publication is undertaken in 2.9 days (median values for papers published in this journal in the second half of 2022

\section{Aims and Scope}

Cells (ISSN 2073-4409) is an international, peer-reviewed open access journal that provides an advanced forum for studies related to cell biology and physiology, molecula biology, and biophysics. We aim to encourage scientists to publish their experimental and theoretical results in as much detail as possible.

The scope of Cells includes:

\section{Cell Structure \\ Cell Physiology}

Cellular Metabolism

Cellular Immunology

Intra- and Extracellular Signaling

Cell Movement and Motility

Autophagy

Apoptosis

Cell Aging, Senescence

Cell Techniques

Cell Growth and Differentiation

Stem Cells

Genetic Disorders and Therapy

Omics

Plant, Algae and Fungi Cell Biology

Neurodegeneration, Neuroinflammation
Section Editors-in-Chief Prof. Dr. Ludger Hengst Dr. Christian Neri

Prof. Dr. Bruce A. Bunnell Dr. Kay-Dietrich Wagner Prof. Dr. Alexander Dityatev Prof. Dr. Suleyman Allakhverdiev Prof Dr Paolo Bernardi Prof. Dr. Christoph Englert Prof. Dr. Alexander V. Ljubimov Prof. Dr. Hiroshi Miyamoto Prof. Dr. Alessandro Pogg Prof. Dr. Fulvio Reggiori Dr. Francisco Rivero Prof. Dr. Naweed I. Syed Prof. Dr. Ritva Tikkanen Prof. Dr. Roger Schneiter Prof. Dr. Yu Xue

Editorial Office Cells Editorial Office cells@mdpi.com MDPI, St. Alban-Anlage 66 4052 Basel, Switzerland Tel: +41 616837734 www.mdpi.com mdpi.com/journal/cells 